\title{
E-LEARNING : ASPEK KEBAHASAAN DALAM IKLAN
}

\author{
Nurmalia Sarah \\ E-mail : nurmaliasarah033@gmail.com \\ Program Studi Pendidikan Bahasa dan Sastra Indonesia, Universitas Riau
}

\section{Pengantar}

Pembelajaran merupakan suatu hal yang penting dalam kehidupan manusia. Sejak manusia lahir, manusia sudah mulai belajar dari keluarga dan lingkungannya. Lalu setelah manusia memasuki usia sekolah, kata pembelajaran sudah masuk ke dalam ranah pendidikan. Dalam ranah pendidikan, pembelajaran diartikan sebagai sebuah proses interaksi antara peserta didik dengan tenaga pendidik ketika kegiatan belajar mengajar berlangsung. Dalam proses interaksi tersebut tentu terdapat materi pembelajaran yang diajarkan oleh tenaga pendidik kepada peserta didik. Terdapat banyak materi pembelajaran salah satunya ialah iklan, materi yang dipelajari dalam mata pelajaran bahasa Indonesia. Dalam materi iklan salah satu subbagian pembahasannya ialah aspek kebahasaaan dalam iklan. Materi ini dapat dipelajari dengan baik jika terdapat ruang dan media pembelajaran yang mendukung proses interaksi antara peserta didik dengan tenaga pendidik. Sebelum adanya covid-19 ruang untuk menunjang proses interaksi dalam pembelajaran ialah kelas. Kelas sebagai prasarana sekolah menjadi ruang untuk berkumpulnya para peserta didik dan tenaga pendidik sehingga terjadi proses interaksi pembelajaran didalamnya dan dapat didukung oleh media pembelajaran yang dibutuhkan untuk menunjang proses pembelajaran. Namun, adanya wabah covid-19 di Indonesia sejak maret 2020 menyebabkan seluruh aktivitas manusia terkendala, salah satu diantaranya pada ranah pendidikan. Pandemi covid-19 menghambat proses pembelajaran, oleh karena itu dibutuhkan sebuah inovasi seperti E-Learning agar pembelajaran tetap terlaksana meskipun dalam keadaan pandemi covid-19.

\section{Tindakan yang dilakukan}




\section{a. E- Learning}

Dalam ranah pendidikan media merupakan sebuah instrumen yang sangat penting dan menjadi salah satu faktor penentu keberhasilan dalam proses pembelajaran, terlebih lagi pada masa pandemi covid-19 seperti saat ini. Kata media pembelajaran berasal dari bahasa latin "medius" yang secara harfiah berarti "tengah", perantara atau pengantar. Dalam bahasa Arab, media perantara atau pengantar pesan dari pengirim kepada penerima pesan (Sunzuphy). Di masa pandemi covid-19 terdapat inovasi baru dalam dunia pendidikan yang dilakukan oleh pemerintah yakni pembelajaran jarak jauh yang dilakukan secara daring. Hal ini dilakukan oleh pemerintah sebagai upaya agar pendidikan tetap terlaksana sehingga peserta didik tidak ketinggalan pembelajaran.

Adanya pandemi covid-19 tidak dapat dijadikan alasan agar pembelajaran terhenti karena pembelajaran dapat berlangsung melalui dua cara yakni secara langsung didalam ruang kelas (luring) maupun tidak langsung yaitu secara daring (Zulhafizh, 2020). Pembelajaran secara daring pada masa pandemi covid-19 dapat dilakukan dengan cara memanfaatkan teknologi yang ada di masa kini. Perkembangan teknologi pada masa kini dapat dikatakan sangat pesat perkembangannya sehingga dapat memudahkan manusia untuk berkomunikasi agar tidak ketinggalan informasi. Oleh karena itu teknologi dimanfaatkan dalam ranah pendidikan sebagai media yang menunjang proses pembelajaran.

E-Learning menjadi salah satu media pembelajaran yang dapat digunakan dalam menunjang proses pembelajaran secara daring. Penggunaan istilah “ $E$ ” pada awal kata $E$ Learnig merujuk pada singkatan electronic, artinya inovasi pembelajaran E-learning menggunakan media elektronik seperti laptop, komputer, notebook, smartphone, dan media elektronik lainnya yang dapat mendukung proses pembelajaran lainnya agar tetap terlaksana. (Elyas, 2018) mengemukakan bahwa E-Learning merupakan sebuah bentuk pembelajaran jarak jauh yang dilakukan melalui media elektronik yang memiliki akses internet untuk membangun proses interaksi antara peserta didik dengan tenaga pendidik sehingga kegiatan pembelajaran dapat tetap terlaksana.

\section{b. Sarana pendukung E-Learning}

E-learning merupakan sebuah inovasi dalam dunia pendidikan. Jika ditinjau secara historis, keberadaan E-learning sudah ada jauh sebelum hadirnya wabah pandemi covid- 
19, namun media ini belum terlalu banyak dijadikan pilihan sebagai media pembelajaran. Kini saat pandemi covid-19 hadir di Indonesia, E-Learning menjadi solusi bagi dunia pendidikan karena dengan adanya E-Learning pembelajaran tetap dapat terlaksana kapan saja dan dimana saja tanpa adanya resiko tertular covid-19 karena ruang interaksinya adalah perangkat teknologi yang membutuhkan akses internet. Perangkat teknologi dapat beroperasi jika didalmnya terdapat aplikasi untuk menghubungkan peserta didik dan tenaga pendidik dalam pembelajaran E-Learning (Fauzi Bakri, 2017).

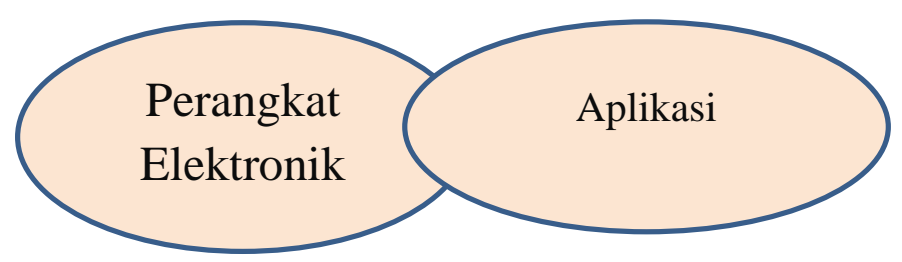

Gambar.1 Keterkaitan Sarana Pendukung E-Learning

Terdapat dua sarana pendukung E-Learning yakni perangkat elektronik dan aplikasi. Perangkat elektronik dan aplikasi dalam pembelajaran E-Learning merupakan dua hal yang saling berkaitan dan tidak dapat dipisahkan. Jika keduanya dipisahkan maka dapat dipastikan proses pembelajaran E-Learning tidak akan dapat terlaksana. Maka dari itu kehadiran perangkat elektronik harus didampingi dengan aplikasi yang dapat mendukung proses pembelajaran E-Learning. Perangkat elektronik berupa alat yang perannya wajib ada sebelum aplikasi. Jika diibaratkan Perangkat elektronik adalah kunci utama berlangsungnya proses pembelajaran E-learning. Sedangkan aplikasi merupakan alat yang harus dimiliki setelah adanya perangkat elektronik.

Perangkat elektronik dikatakan sebagai alat wajib dan kunci utama karena perangkat elektronik merupakan alat yang dapat memfasilitasi proses pembelajaran. E-Learning dapat berjalan jika peserta didik dan tenaga pendidik memiliki alat untuk melakukan proses pembelajaran. Perangkat elektronik ini berupa komputer, laptop, notebook, tablet, ipad, smartphone baik android maupun iphone. Jika salah satu dari perangkat tersebut telah dimiliki oleh tenaga pendidik dan peserta didik maka dapat dipastikan proses pembelajaran dapat dilaksanakan dengan baik. Hadirnya perangkat elektronik tersebut mewajibkan kita sebagai manusia agar dapat menggunakannya dengan baik terlebih lagi perangkat ini digunakan untuk memudahkan proses pembelajaran. 
Setelah memiliki salah satu perangkat elektronik tersebut maka perangkat itu harus didampingi dengan aplikasi belajar. Dalam pembelajaran E-Learning terdapat beberapa sekolah yang sudah menggunakan web maupun portal yang sudah diciptakan oleh pihak sekolah. Namun tampaknya hal demikian belum dapat dilaksanakan oleh semua pihak sekolah, maka beberapa sekolah ada yang mengarahkan tenaga pendidiknya untuk menggunakan aplikasi yang sudah ada dan dapat diunduh secara gratis baik oleh tenaga pendidik maupun peserta didik. Beberapa aplikasi tersebut ialah google meet, zoom, google classroom, whatsapp, youtube, email, telegram, quiziz, etmodo, dan aplikasi lainnya sesuai kebutuhan dalam pembelajaran.

Sarana pendukung tersebut dapat mempermudah jalannya proses pembelajaran $E$ Learning jika adanya jaringan internet didalamnya. Dalam pelaksanaan E-Learning internet bagikan nyawa yang dapat menghidupkan proses pembelajaran. Tanpa adanya jaringan internet tentu saja proses pembelajaran E-Learning tidak akan dapat terlaksana. Jaringan internet dapat diperoleh jika seseorang berada di tempat yang bagus jaringannya, serta memiliki kuota internet untuk mengakses aplikasi yang berada didalam perangkat elektronik, jika kuota internet tidak dimiliki maka ada solusi lain yakni menggunakan wifi. Oleh karena itu sebelum proses pembelajaran E-Learning berlangsung maka hal-hal tersebut harus dipersiapkan agar pembelajaran dapat berjalan maksimal.

\section{c. Iklan}

Salah satu materi pembelajaran dalam mata pelajaran bahasa Indonesia ialah iklan. Iklan adalah salah satu bentuk kegiatan komunikasi melalui media yang didalamnya berisi informasi serta bertujuan untuk menarik minat konsumen pada hal yang ditawarkan baik berupa barang maupun jasa. Sebuah iklan dapat dikatakan efektif jika iklan yang ditampilkan memberi reaksi bagi konsumen sesuai harapan pencipta iklan. Oleh karena itu, aspek kebahasaan dalam iklan menjadi unsur yang paling penting dalam iklan karena unsur kebahasaan menjadi titik tolak keefektifan sebuah iklan. Maka dari itu kebahasaan dalam iklan harus bersifat persuasif, informatif, dan mempunyai daya tarik tinggi (Drs. Suharyo) 


\section{IKLAN}

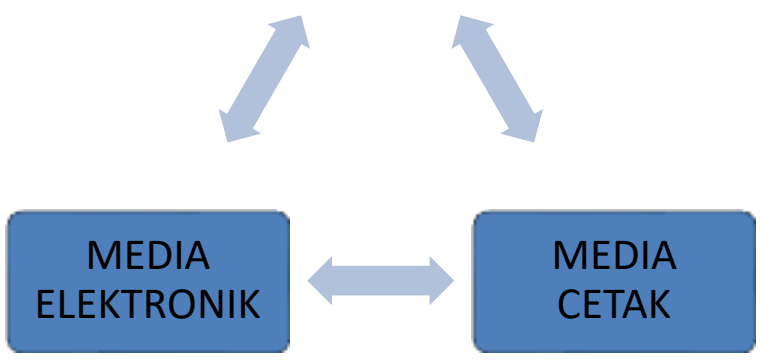

Gambar 2. Media iklan

Iklan dapat ditemui baik pada media elektronik maupun pada media cetak. Media elektronik seperti televisi, radio, smartphone, laptop, dan notebook biasanya menyajikan banyak sekali iklan. Iklan yang berada di televisi dan radio biasa ditayangkan disela-sela tayangan yang berlangsung, namun khusus pada smartphone, laptop, dan notebook iklan biasanya akan tayang jika perangkat tersebut terhubung dengan jaringan internet dan saat kita memainkan sebuah aplikasi didalamnya seperti youtube. Iklan juga dapat ditemui pada media cetak seperti dalam majalah dan koran. Oleh karena itu iklan dapat dikatakan sebagai materi pembelajaran yang mudah ditemui.

\section{d. Inovasi E-Learning Aspek kebahasaan dalam iklan}

(Sedya Santosa, 2021) berpendapat bahwa di situasi pandemi covid-19 seperti saat ini, tenaga pendidik dituntut untuk melakukan inovasi dalam pembelajaran. Inovasi dalam pembelajaran ini dapat dilakukan melalui E-learning dengan metode pembelajaran yang menarik. Metode pembelajaran yang menarik dapat menciptakan suasana pembelajaran yang aktif, inspiratif, suasana yang menyenangkan, sehinnga dapat memberi motivasi untuk peserta didik agar berpartisipasi, berpikir kritis, dan mengembangkan kreativitasnya secara mandiri dalam lingkup pembelajaran. Pembelajaran seperti ini dapat terlaksana jika terjalin kerjasama yang baik antara tenaga pendidik dan peserta didik dalam situasi dan kondisi seperti saat ini.

Dalam kondisi pembelajaran E-Learning seperti saat ini maka diharapkan kualitas dan kuantitas pembelajaran tidak berkurang. Tenaga pendidik dan peserta didik harus dapat beradaptasi dengan keadaan pandemi covid-19 saat ini. Tenaga pendidik harus dapat 
memotivasi anak untuk berpartisipsi aktif dalam pembelajaran sedangkan peserta didik harus dapat mengembangkan kemandiriannya dalam proses pembelajaran, dengan cara berpikir secara kritis dan kreatif. Jika kesadaran ini telah dimiliki oleh tenaga pendidik dan peserta didik maka dapat dipastikan inovasi pembelajaran E-Learning dapat terlaksana dengan baik dan berkualitas sehingga proses pembelajaran E-Learning tidak hanya terjadi sebatas formalitas dalam ranah pendidikan (Zulhafizh S. P., 2020).

Salah satu materi yang dapat dikembangkan secara menarik oleh tenaga pendidiknya ialah iklan. Dalam materi iklan aspek yang paling menarik untuk dibahas ialah aspek kebahasaan. Kebahasaan dalam iklan merupakan wujud penyampaian informasi dan pesan dari pencipta iklan untuk menarik dan meraih simpati khalayak. Hal ini kemudian menjadi ciri khas dalam sebuah iklan yang membedakan iklan dengan wacana lainnya baik secara lisan ataupun tulisan. Iklan juga erat kaitannya dengan gaya bahasa yang bersifat persuasi (ajakan) karena iklan bertujuan untuk mempengaruhi masyarakat agar tertarik dengan hal yang diiklankan dan membelinya.

Materi iklan mengenai aspek kebahasaan dapat dilakukan dalam proses inovasi pembelajaran E-Learning. Materi ini dapat dijelaskan oleh tenaga pendidik terlebih dahulu melalui aplikasi pembelajaran seperti google meet guna memberikan ilmu pengetahuan kepada peserta didik. Setelah itu maka tenaga pendidik dapat memberikan tugas bagi para peserta didik untuk menganalisis aspek kebahasaan dalam iklan. Dengan adanya pemberian tugas maka diharapkan peserta didik mampu berpikir secara krisis dan kreatif dalam menganalisis aspek kebahasaan iklan sehingga hal ini membuat para peserta didik lebih memahami materi yang telah diajarkan oleh sang guru. Sang guru juga dapat menilai pemahaman peserta didiknya melalui tugas yang dikumpulkan oleh mereka.

\section{Sarana Pendukung}
a. Laptop
b. Smartphone
c. Kuota Internet
d. Jaringan
e. Google meet 
f. Televisi ( Mencari iklan di televisi untuk dianalisis aspek kebahasaannya)

g. Youtube Mencari iklan di youtube untuk dianalisis aspek kebahasaannya)

h. Internet (Mencari iklan di internet untuk dianalisis aspek kebahasaannya)

i. Majalah (Mencari iklan di majalah untuk dianalisis aspek kebahasaannya)

j. Google Classroom (Tempat pengumpulan tugas)

k. Email (Tempat pengumpulan tugas)

\section{Tindakan Solutif}

a. Jika terdapat murid yang tidak memiliki laptop maka dapat menggunakan smartphone

b. Jika terdapat murid yang tidak memiliki smartphone maka dapat ke warnet atau meminjam perangkat elektronik orang lain

c. Jika terdapat murid yang tidak memiliki kuota internet maka dapat mencari wifi gratis

d. Jika terdapat murid yang terkendala jaringan maka dapat berpindah tempat ke daerah jaringan yang lebih baik saat belajar

e. Jika terdapat kendala saat menggunakan aplikasi google meet maka dapat menggunakan zoom

f. Jika murid tidak menemukan iklan yang akan dianalisis di TV maka dapat mencari di youtube

g. Jika murid tidak menemukan iklan yang akan dianalisis di youtube maka dapat mencari di internet

h. Jika murid tidak menemukan iklan yang akan dianalisis di internet maka dapat mencari di majalah

i. Jika murid tidak menemukan iklan yang akan dianalisis di majalah maka dapat mencari di koran

j. Jika terdapat kendala saat menggunakan aplikasi google classroom ketika mengumpulkan tugas maka dapat mengirimkan di email

k. Jika terdapat kendala saat menggunakan aplikasi email ketika mengumpulkan tugas maka dapat mengirimkan di whatsapp atau telegram.

\section{Simpulan}


Hadirnya pandemi covid-19 mengubah bentuk dan sistem pembelajaran dalam ranah pendidikan. Pembelajaran yang semula dilakukan di sekolah kini harus dilaksanakan secara jarak jauh sebagai upaya memutus mata rantai penyebaran covid19. Oleh karena itu dibutuhkan sebuah sistem pembelajaran baru agar pembelajaran tetap berlangsung dan pendidikan Indonesia tetap berjalan. Salah satu upaya yang dapat dilakukan untuk mengatasi hal tersebut ialah E-Learning. Kecanggihan zaman pada saat ini dapat dimanfaatkan oleh ranah pendidikan untuk memberlakukan $E$ Learning di masa pandemi ini.

E-learning merupakan sebuah sistem pembelajaran jarak jauh yang dilakukan melalui media elektronik yang memiliki akses internet untuk membangun proses interaksi antara peserta didik dengan tenaga pendidik sehingga kegiatan pembelajaran dapat tetap terlaksana. Dalam pelaksanaan E-learning dibutuhkan dua sarana pendukung yakni perangkat elektronik dan aplikasi. Kedua sarana pendukung tersebut dapat mempermudah jalannya proses pembelajaran E-Learning jika adanya jaringan internet didalamnya. Jika sarana pendukung dalam pelaksanaan E-Learning tidak ada maka dapat dilakukan dengan cara melakukan tindakan solutif. Upaya-upaya ini dilaksanakan agar pembelajaran tetap dapat terlaksana.

Dalam kegiatan pembelajaran materi adalah salah satu hal terpenting yang harus ada karena hal itu merupakan dasar terjadinya interaksi dan proses pembelajaran. Salah satu materi dalam pembelajaran bahasa Indonesia ialah iklan. Iklan adalah salah satu bentuk kegiatan komunikasi melalui media yang didalamnya berisi informasi serta bertujuan untuk menarik minat konsumen pada hal yang ditawarkan baik berupa barang maupun jasa. iklan menjadi menarik karena aspek kebahasaan yang dimilikinya. Seorang guru bahasa Indonesia dapat memaparkan materi ini dengan cara menarik agar siswa paham setelah itu untuk mengukur pemahaman siswa, guru dapat memberikan tugas untuk menganalisis aspek kebahasaan dalam sebuah iklan. Hal ini tentu dapat mendorong pemikiran siswa menjadi lebih krisis dalam menganalisis sebuah iklan sehingga materi ini dapat dipahami dengan baik oleh siswa.

\section{Referensi}


Drs. Suharyo, M. S. (n.d.). Struktur Iklan Dalam Bahasa Indonesia.

Elyas, A. H. (2018). PENGGUNAAN MODEL PEMBELAJARAN E-LEARNING DALAM . Jurnal Warta Edisi.

Fauzi Bakri, D. M. (2017). Pengembangan Perangkat E-Learning Untuk Matakuliah Fisika DasarII Menggunakan LMS Chamilo. Jurnal Wahana Pendidikan Fisika Vol.2 No.1, 25-30.

Sedya Santosa, A. M. (2021). Pengembangan Materi Bahasa Indonesia Analisis Iklan Melalui Edukasi Penanganan COVID-19. JURNAL BASICEDU, 1444 - 1449.

Sunzuphy, C. (n.d.). Media pembelajaran. Jakarta: PT. Raja Grafindo Persada.

Zulhafizh. (2020). Membina Aktivitas Belajar Mahasiswa di Perguruan Tinggi. Jurnal Kependidikan, 502-511.

Zulhafizh, S. P. (2020). Developing Quality Of Learning In The Pandemic Covid-19 Through Creative And Critical Thingking Attitudes. Jurnal Pajar(Pendidikan dan Pengajaran)Vol.4 No.5, 937-949. 


\section{*Data Penulis}

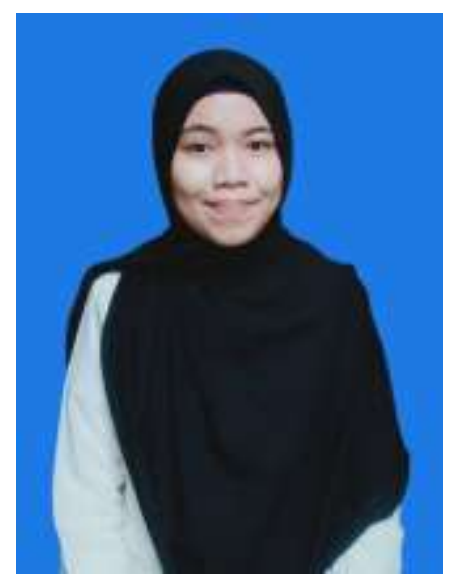

Nurmalia Sarah, lahir di Pekanbaru, 14 Juni 2002. Ia merupakan anak pertama dari tiga bersaudara. Pada tahun akademik 2020, Ia lulus dari SMA Negeri 12 Pekanbaru. Setelah itu ditahun yang sama ia melanjutkan studi pada strata satu Jurusan Pendidikan Bahasa dan Seni di Program Studi Pendidikan Bahasa dan Sastra Indonesia FKIP Universitas Riau melalui jalur SNMPTN (Seleksi Nasional Masuk Perguruan Tinggi Negri). Pada saat ini, Ia sudah semester 3 dan terdapat beberapa prestasi yang ia miliki seperti menjuarai lomba sholat jenazah, menjuarai lomba tulis puisi tingkat nasional, menjuarai lomba tulis dan baca puisi tingkat SMA, menjuarai lomba standup comedy, dan peserta olimpiade OSN bidang geografi. Karya yang telah ia hasilkan masih belum dibukukan namun ia memiliki karya seperti puisi, cerpen, dan cerita yang pernah ia unggah dalam akun wattpad pribadi miliknya. la berharap dapat menyelesaikan studinya dengan waktu yang singkat di Program Studi Pendidikan Bahasa dan Sastra Indonesia, Universitas Riau.

Kontak :

HP/WA : :082286968995

Email : nurmaliasarah033@gmail.com 